\title{
Comparison of greenhouse gas emissions from Mexican intensive dairy farms
}

\author{
J. A. Rendón-Huerta ${ }^{1}$, J. M. Pinos-Rodríguez ${ }^{2 \#}$, E. Kebreab ${ }^{3}$, J. C. García-López ${ }^{1}$ \& J. G. \\ Vicente ${ }^{2}$ \\ ${ }^{1}$ Coordinación Académica Región Altiplano Oeste e Instituto de Investigación de Zonas Desérticas Universidad \\ Autónoma de San Luis Potosí, 78000, S.L.P. México \\ ${ }^{2}$ Facultad de Medicina Veterinaria y Zootecnia \\ Universidad Veracruzana, 91710, Veracruz, México \\ ${ }^{3}$ Department of Animal Science \\ University of California, Davis, 95616, California, USA
}

(Received 3 May 2017; Accepted 1 November 2017; First published online 8 November 2017)

\author{
Copyright resides with the authors in terms of the Creative Commons Attribution 4.0 South African Licence. \\ See: http://creativecommons.org/licenses/by/4.0/za \\ Condition of use: The user may copy, distribute, transmit and adapt the work, but must recognise the authors and the South African \\ Journal of Animal Science.
}

\begin{abstract}
The objectives of this study were to compare estimates of greenhouse gas emissions (GHG) as $\mathrm{CH}_{4}$ (enteric-manure), $\mathrm{N}_{2} \mathrm{O}$ (manure), and $\mathrm{CO}_{2}$ (fuel and energy use), the use of water and soil, the excretion of nutrients in manure, and feed efficiency from Mexican intensive dairy farms. Data from 26 dairy farms were analysed with a multivariable cluster analysis. Three grades of intensifications were identified (low, medium and high). Mathematical models were used to estimate GHG. Feed efficiency (kg milk per $\mathrm{kg} \mathrm{DMI}$ ) was better in high intensive production systems. Enteric methane was identified as the major source of GHG in all types of systems. High intensive dairies generated the lowest emissions of $\mathrm{CH}_{4}, \mathrm{~N}_{2} \mathrm{O}$ and $\mathrm{CO}_{2}$ equivalent by unit of product, $18.6 \mathrm{~g}, 0.12 \mathrm{~g}$ and $828 \mathrm{~g}$, respectively. Water footprint was lower in low intensive dairies using $427 \mathrm{~L}$ of water/L of milk. Cropland was highest in intensive systems but milk yield per area was better $(30,938 \mathrm{~kg} / \mathrm{ha})$. Excretions of N, P, and $\mathrm{K}$ were lower in intensive dairies per $\mathrm{kg}$ of milk, at 13.2, 2.4, and 6.4 $\mathrm{g}$, respectively. As intensification in the dairy system increased feed efficiency (kg milk/kg DMI) was better. Per unit of product ( $\mathrm{kg}$ of milk), dairies with the highest intensification generated the lowest GHG emissions, nutrient excretion values and land and water use as compared to dairies with medium and low intensification. Increasing intensification and therefore feed efficiency of Mexican dairy systems could help to decrease GHG emissions, natural resources use and nutrient excretion.
\end{abstract}

Keywords: Carbon footprint, environmental impact, methane, milk production

\#Corresponding author: jpinos@uv.mx

\section{Introduction}

In México, the milk production process is developed in technological, socioeconomic, and agroecological heterogeneous conditions with four different kinds of systems: intensive, semi-intensive, rural, and dual purpose. Livestock production is recognized to contribute significantly to emission of greenhouse gases (GHG) into the agriculture sector, mainly through emission of methane $\left(\mathrm{CH}_{4}\right)$ and nitrous oxide $\left(\mathrm{N}_{2} \mathrm{O}\right)$ (Steinfeld et al., 2006). The global dairy sector contributes 4.0 percent $\left(1,969\right.$ Million tonnes $\mathrm{CO}_{2}$-eq) to the total global anthropogenic GHG emissions (FAO, 2010). Capper et al. (2009) pointed out that nowadays the dairy production practices have a lower environmental impact than those of the 1940s. Efficiency of production is defined as the minimum quantity of inputs (feed, fossil fuels) and emissions of GHG and nutrients in order to produce a certain quantity of milk (Place \& Mitloehner, 2010). The variety of milk production systems, but mainly intensive systems, make use of better nutritional feeds produced with inorganic and organic fertilizers (Smith, 1991; Capper et al., 2009), where in many scenarios losses of nutrient in manure (faeces and urine) can occur. In particular, nitrogen, phosphorus, and potassium, when they are present in excess, can have a negative impact on the environment (atmosphere, soil and water), human health and wild animals (Kojima et al., 2005). Milk production systems also require other kinds of inputs, such as fuels and electric energy, which contributes to $\mathrm{CO}_{2}$ emission from combustion of fossil fuels to power machinery, or electric energy generation (Rotz et al., 2010). Gas measurements, such as $\mathrm{CH}_{4}$, 
$\mathrm{N}_{2} \mathrm{O}$, and $\mathrm{CO}_{2}$, are complex and require expensive equipment; one alternative has been the development and use of mathematical models to estimate GHG emissions (Kebreab et al., 2008). Mathematical models allow prediction of GHG emissions from ruminants related to the intake of nutrients without performing costly experiments (Kebreab et al., 2006). At the same time, another concept that applies to animal production is the water footprint, which is analogous to the ecological and the carbon footprint, but indicates fresh water use instead of land or fossil energy use and GHG emissions (Hoekstra, 2003). Therefore, the objective of this study was 1) to compare estimations of $\mathrm{CH}_{4}$ (enteric and manure), $\mathrm{N}_{2} \mathrm{O}$ (manure), and $\mathrm{CO}_{2}$ (fuel and energy use) emissions in different kinds of intensive dairy farms in México, and 2) to estimate the use of natural resources such as water and soil, efficiency of production and excretion of nutrients in manure such as $\mathrm{N}, \mathrm{P}$, and $\mathrm{K}$ in different milk production systems.

\section{Material and methods}

A face-to-face, on-farm questionnaire was conducted. The same questionnaire was used on each dairy. Data on animal performance, diet composition, manure and soil samples from lactating, dry heifers and bulls, were collected from 26 dairy farms in Central and North of México (Queretaro, Jalisco, Guanajuato and Aguascalientes). Ration and manure samples of each ranch were kept frozen at $-20^{\circ} \mathrm{C}$ until they were analysed. For feed and manure samples, analysis of dry matter content, crude protein, fat, ash (AOAC, 1990) NDF and ADF (Van Soest et al., 1991), where done in order to fit the COWPOLL model and analyse nutrient losses, respectively. In order to classify the extent of intensification among various livestock systems, a multivariable cluster analysis was made using Cluster function of $R$ statistical software ( $R$ Development Core Team, 2012).

To estimate enteric fermentation, manure $\mathrm{CH}_{4}$ and $\mathrm{N}_{2} \mathrm{O}$, a mechanistic model COWPOLL (based on Dijkstra et al., 1992), and two empirical models (IPCC, 2006) were selected based on input data requirement, their ease of application, and widespread use to predict $\mathrm{CH}_{4}$ and $\mathrm{N}_{2} \mathrm{O}$ emissions and also their potential relevance to Mexican dairy production system, due to a lack of information on environmantal impact by dairy farms in Mexico.

As described by Rendón-Huerta et al. (2013), enteric and manure $\mathrm{CH}_{4}$ emissions were estimated with COWPOLL (Dijkstra et al.,1992) and IPCC (2006), respectively. Manure $\mathrm{N}_{2} \mathrm{O}$ emissions were calculated as $0.001 \mathrm{~kg}$ of $\mathrm{N}_{2} \mathrm{O}$ per $\mathrm{kg}$ of $\mathrm{N}$ excreted (IPCC, 2006); however, the estimations did not include $\mathrm{N}_{2} \mathrm{O}$ emissions from inorganic fertilizers. Carbon dioxide emissions from animal respiration were not considered due to $\mathrm{CO}_{2}$ sequestration by plants in the photosynthesis process. For carbon footprint, the global warming potential of $\mathrm{CO}_{2}, \mathrm{CH}_{4}$, and $\mathrm{N}_{2} \mathrm{O}$ were 1, 34, and 298, respectively, on the basis of IPCC (2013) recommendations. Carbon dioxide from fuels and electric energy utilization were obtained through a questionnaire. According to the US EPA (2016), emissions from $1 \mathrm{kWh}$ energy use, $1 \mathrm{~L}$ gasoline, and $1 \mathrm{~L}$ of diesel burned are equivalent to $0.73,2.33$, and $2.83 \mathrm{~kg}$ of $\mathrm{CO}_{2}$ equivalents. For nutrient excretion, the efficiency of nitrogen $(\mathrm{N})$, phosphorus $(\mathrm{P})$, and potassium $(\mathrm{K})$ utilization were analyzed. Chemical analysis of nutrients $(\mathrm{N}, \mathrm{P}$, and $\mathrm{K})$ in feed and manure samples, as well as dry matter content was carried out (AOAC, 1990).

Information on land used for pens, milking facility, and cropland were collected through a questionnaire. Similarly, information on main crops grown and yields per ha were collected. Water footprint was calculated considering the green water, defined as water from rainfalls; data of precipitation was taken from climatological stations close to each dairy (Servicio Metereologico Nacional, 2017). The blue water was considered, which is defined as water consumption for irrigation crops, cleaning, and drinking water from wells. It was calculated according to volume flow rate equation based on pumping time and seasons during the year:

$$
Q=A v,
$$

where: $Q$ is the water flow rate in $\mathrm{m}^{3} / \mathrm{s}$,

$A$ is the pipe section area in $\mathrm{m}^{2}$, and

$v$ is the average flux velocity in $\mathrm{m} / \mathrm{s}$ (Mott, 1996).

In order to classify the extent of intensification among various livestock systems a multivariable cluster analysis was made using Cluster function of $R$ statistical software ( $R$ Development Core Team, 2012). The variables considered were cow population, cropland, electricity use, fossil fuels and water consumption. Comparison of GHG emissions, water footprint and nutrient excretion were analysed with a completely randomized design through an analysis of variance (ANOVA). Comparison of GHG, milk production, DMI and efficiency of production were performed through a Pearson correlation. When differences were found means were compared using the Tukey test $(P<0.05)$. 


\section{Results and discussion}

According to the Cluster analysis, three kinds of intensive systems were identified as low, medium, and high production intensity. The average total animal populations in the three categories of production were 285, 588, and 1940, respectively. Lactating cows made up 128, 281, and 786 animals in low, medium and high intensive systems, respectively (Table 1). Highest milk yield values by cow per day were obtained in high intensive dairies compared with medium and low intensive dairies $(31.4,29.6$ and $25.9 \mathrm{~kg}$, respectively; $P<0.001$ ). Total milk production values per year were highest in high intensive compared to low intensive systems (7.52 vs. 1.21 Mtonne milk, respectively; $P<0.0001$ ). Production efficiency (milk per $\mathrm{kg}$ of feed intake) was found to be highest in the largest dairies in contrast to small dairies $(1.31 \mathrm{vs} .1 .07 \mathrm{~kg} \mathrm{milk} / \mathrm{kg}$ of DMl; $P<0.05)$. This effect was mainly due to the diet composition, where in high intensive dairies the forage: concentrate ratio (F: C) averaged 45:55 and medium and low intensive dairies $\mathrm{F}$ : C averaged 52:48 and 60:40, respectively. Silage corn and alfalfa were the main forage in diets, while commercial concentrate and corn (TMR) were in the concentrate proportion.

Table 1 Animal population distribution by category and milk production in three different intensive systems

\begin{tabular}{|c|c|c|c|c|c|}
\hline & \multicolumn{3}{|c|}{ Level of intensification } & \multirow{2}{*}{ SEM } & \multirow{2}{*}{$P$-value } \\
\hline & Low & Medium & High & & \\
\hline \multicolumn{6}{|l|}{ Category } \\
\hline Early lactation cows & 115 & 237 & 590 & 29.2 & *** \\
\hline Mid-lactation cows & 15 & 35 & 154 & 46.7 & ** \\
\hline Late lactation cows & 4 & 9 & 42 & 16.5 & ns \\
\hline Dry cows & 28 & 38 & 135 & 16.8 & ** \\
\hline Heifers & 88 & 153 & 400 & 9.17 & $* * *$ \\
\hline Calves & 43 & 93 & 589 & 55.8 & $* * *$ \\
\hline Bulls & 2 & 23 & 31 & 23.8 & ns \\
\hline Total & 295 & 588 & 1941 & 67.5 & $* * *$ \\
\hline Milk yield, kg/cow.d & 25.9 & 29.6 & 31.4 & 1.05 & ** \\
\hline Milk yield, $\mathrm{kg} /$ cow. $\mathrm{yr} \times 10^{3}$ & 7.89 & 9.02 & 9.57 & 0.31 & ** \\
\hline Total milk production, $\mathrm{kg} / \mathrm{yr} \times 10^{6}$ & 1.21 & 2.53 & 7.52 & 0.49 & *** \\
\hline $\mathrm{DMI}, \mathrm{kg} / \mathrm{d}$ & 24.1 & 23.2 & 23.9 & 0.84 & ns \\
\hline Efficiency, kg milk /kg DMI & 1.07 & 1.27 & 1.31 & 0.05 & * \\
\hline
\end{tabular}

SEM $=$ Standard error of the mean; $\mathrm{DMI}=$ dry matter intake

${ }^{*}=P<0.05,{ }^{* *}=P<0.01,{ }^{* * *}=P<0.001$, ns $=$ non-significant.

Greenhouse gases estimated in this trial were enteric $\mathrm{CH}_{4}$, manure $\mathrm{CH}_{4}$ and $\mathrm{N}_{2} \mathrm{O}$, and $\mathrm{CO}_{2}$ from electric energy use and fuels combustion (Table 2). Estimates of total enteric methane was greater in high intensive dairies followed by medium and low intensive dairies, 379, 148 and $70.6 \mathrm{~kg} / \mathrm{d}(P<0.0001)$. The differences were in function of herd size, with similar trend for total manure methane, manure nitrous oxide, carbon dioxide emissions from energy and fuel consumption, and total carbon dioxide equivalent emissions.

Estimated manure $\mathrm{CH}_{4}$ emissions per cow were significantly different $(P<0.0001)$ in all categories with the highest values obtained from low intensive systems compared to medium and high intensive systems (55.4, 49.4, and $41 \mathrm{~g} / \mathrm{d}$, respectively). Enteric $\mathrm{CH}_{4}$ emissions were similar, however, enteric $\mathrm{CH}_{4}$ was identified as the greatest source of $\mathrm{GHG}$ in $\mathrm{CO}_{2} \mathrm{e}$ defined as $\mathrm{CO}_{2}$ e equivalent followed by energy and fuels consumption. Total $\mathrm{CH}_{4}$ per cow were similar to those found by Aguerre et al. (2011), who point out that cows fed diets with $\mathrm{F}$ : $\mathrm{C}$ ratio of $47: 53$, produced $538 \mathrm{~g} \mathrm{CH}_{4} / \mathrm{d}$ and, as the forage proportion increased, $\mathrm{CH}_{4}$ emissions increased as well. Although their value was greater compared to those obtained in our study, the authors admitted that their values were greater to chambers measurements. 
Table 2 Greenhouse gas emissions by three different intensive systems

\begin{tabular}{|c|c|c|c|c|c|}
\hline & \multicolumn{3}{|c|}{ Level of intensification } & \multirow{2}{*}{ SEM } & \multirow{2}{*}{$P$-value } \\
\hline & Low & Medium & High & & \\
\hline Total cows & 285 & 588 & 1940 & 136 & $* * *$ \\
\hline Lactating cows & 134 & 281 & 786 & 51 & $* \star *$ \\
\hline Total milk production, $\mathrm{kg} / \mathrm{d}$ & 3470.6 & 8317.6 & 24680 & 1197 & $* * *$ \\
\hline Milk yield, $\mathrm{kg} / \mathrm{cow} / \mathrm{d}$ & 25.9 & 29.6 & 31.4 & 1.05 & ** \\
\hline \multicolumn{6}{|c|}{ GHG emissions from whole system, $\mathrm{g} / \mathrm{d}$} \\
\hline Enteric $\mathrm{CH}_{4} \times 10^{3}$ & 70.6 & 147.5 & 379.3 & 20.3 & $* * *$ \\
\hline Manure $\mathrm{CH}_{4} \times 10^{3}$ & 15.8 & 29 & 79.5 & 4.8 & $* * *$ \\
\hline Total $\mathrm{CH}_{4} \times 10^{3}$ & 86.4 & 176.6 & 458.9 & 25 & $* * *$ \\
\hline Manure $\mathrm{N}_{2} \mathrm{O} \times 10^{3}$ & 0.56 & 1.01 & 3.05 & 0.18 & $* * *$ \\
\hline Energy \& Fuel $\mathrm{CO}_{2} \mathrm{e} \times 10^{6}$ & 1.74 & 2.22 & 8.06 & 0.19 & $* \star *$ \\
\hline Total $\mathrm{CO}_{2} \mathrm{e} \times 10^{6}$ & 4.84 & 8.52 & 24.5 & 0.76 & $* * *$ \\
\hline \multicolumn{6}{|c|}{ GHG emissions for lactating cow, $\mathrm{g} / \mathrm{d}$} \\
\hline Enteric $\mathrm{CH}_{4}$ & 469 & 459 & 456 & 12.3 & ns \\
\hline Manure $\mathrm{CH}_{4}$ & 55.4 & 49.4 & 41 & 2.3 & $* * *$ \\
\hline Total $\mathrm{CH}_{4}$ & 524.4 & 507.4 & 497 & 4.3 & $* * *$ \\
\hline Manure $\mathrm{N}_{2} \mathrm{O}$ & 4.21 & 5.38 & 3.83 & 0.77 & ns \\
\hline Energy \& Fuel $\mathrm{CO}_{2} \mathrm{e} \times 10^{3}$ & 8.29 & 5.70 & 6.13 & 1.38 & ns \\
\hline Total $\mathrm{CO}_{2} \mathrm{e} \times 10^{3}$ & 27.4 & 24.5 & 24.2 & 4.4 & ns \\
\hline \multicolumn{6}{|c|}{${ }^{¥} G H G$ emissions for unit product, $g / L$} \\
\hline Enteric $\mathrm{CH}_{4}$ & 20.4 & 17.7 & 15.4 & 1.35 & ** \\
\hline Manure $\mathrm{CH}_{4}$ & 4.5 & 3.5 & 3.2 & 0.28 & $* * *$ \\
\hline Total $\mathrm{CH}_{4}$ & 24.9 & 21.2 & 18.6 & 1.80 & ** \\
\hline Manure $\mathrm{N}_{2} \mathrm{O}$ & 0.16 & 0.12 & 0.12 & 0.008 & $* * *$ \\
\hline Energy \& Fuel $\mathrm{CO}_{2} \mathrm{e}$ & 501.7 & 267 & 327 & 55.3 & ns \\
\hline Total $\mathrm{CO}_{2} \mathrm{e}$ & 1396 & 1023 & 995 & 77.3 & ** \\
\hline
\end{tabular}

Emissions per unit of product were different $(P<0.05)$. For enteric $\mathrm{CH}_{4}$, the greatest values were estimated from the low intensive dairy systems, followed by medium, and high intensive dairy systems (21.7, 18.6, and $15 \mathrm{~g} / \mathrm{L}$ of milk, respectively). Emissions from intensive farms were similar with those found by Aguerre et al. (2011), who showed that cows fed diets with 47:53 F: C ratio and intake of $21 \mathrm{~kg}$ DM produced $14.0 \mathrm{~g}$ of $\mathrm{CH}_{4} / \mathrm{kg}$ of milk. Although there was a difference in DMI between our study and the authors', the main differences may be attributed to type of feed ingredients in diet such as soybean extract, roasted soybeans, etc. According to Hristov et al. (2013), there are some practices that could increase milk production and reduce enteric methane reduction. These practices include improving forage quality, and optimizing rumen function for higher microbial protein synthesis through feeding of a balanced diet. Manure (faeces and urine) are mainly stored for about 4 to 6 months before application to crops as fertilizer. Manure $\mathrm{CH}_{4}$, and total $\mathrm{CH}_{4}$ were statistically significant as well. Nitrous oxide estimations were highest in low intensive dairy systems $0.16 \mathrm{~g} / \mathrm{L}$ of milk $(P<0.001)$. Even if highly intensive systems use high quantity of energy (electric and fuels) in order to produce milk, emissions of $\mathrm{CO}_{2}$ were highest in low intensive dairies compared to medium and high intensive dairies $(P<0.005)$. Finally total $\mathrm{CO}_{2}$ equivalent $\left(\mathrm{CO}_{2} \mathrm{e}\right)$ emissions per litre of milk were found significantly different $(P<0.05)$. The highest values were obtained in low intensive dairies, followed by medium, and high intensive dairies (1.39, 1.02 , and $0.99 \mathrm{~kg} \mathrm{CO}_{2} \mathrm{e} / \mathrm{L}$ of milk). Methane was the highest source of GHG, followed by energy and fuel consumption. These results agree with those 
found by Rotz el at. (2010). The results were also in close agreement to those reported by Hörtenhuber et al. (2010) who found emissions up to the farm gate ranging from 0.90 to $1.17 \mathrm{~kg} \mathrm{CO}_{2} \mathrm{e} / \mathrm{kg}$ milk. Phetteplace et al. (2001) found that for a cow producing $7,880 \mathrm{~kg}$ milk per year, the carbon footprint was $1.09 \mathrm{~kg} \mathrm{CO} 2 \mathrm{e} / \mathrm{kg}$ of milk. Capper et al. (2008) reported that a lactating cow producing $9,050 \mathrm{~kg}$ of milk generated $1.5 \mathrm{~kg} \mathrm{CO} \mathrm{C}_{2} \mathrm{e} / \mathrm{kg}$ of milk, the difference between this last value and our values may be due that the farms that we visited do not produce the total feeds.

A Pearson correlation (Table 3), indicates that increasing milk production (kg milk/kg DMI), decreased $(P<0.05) \mathrm{CH}_{4}, \mathrm{~N}_{2} \mathrm{O}$ and $\mathrm{CO}_{2}$ per unit of product.

Table 3 Pearson correlation coefficients for efficiency, lactating cows, milk production and GHG

\begin{tabular}{lccc}
\hline & Efficiency & Lactating cows & Milk production/d \\
\hline & 1.00000 & 0.38284 & 0.47965 \\
Efficiency & & 0.0648 & 0.0177 \\
& 0.47965 & 0.95148 & 1.0000 \\
Milk production/d & 0.0177 & $<.0001$ & \\
& 0.06270 & -0.19864 & -0.04914 \\
$\mathrm{CH}_{4}$ per cow & 0.7710 & 0.3521 & 0.8196 \\
& 0.18762 & -0.25656 & -0.06442 \\
$\mathrm{~N}_{2} \mathrm{O}$ per cow & 0.3800 & 0.2262 & 0.7649 \\
& 0.07249 & -0.35132 & -0.14806 \\
$\mathrm{CO}_{2}$ per cow & 0.7364 & 0.0923 & 0.4899 \\
& -0.39429 & -0.58271 & -0.59812 \\
$\mathrm{CH}_{4}$ per $\mathrm{L}$ of milk & 0.0566 & 0.0028 & 0.0020 \\
& -0.55534 & -0.57879 & -0.64581 \\
$\mathrm{~N}_{2} \mathrm{O}$ per $\mathrm{L}$ of milk & 0.0048 & 0.0030 & 0.0007 \\
& -0.56895 & -0.53776 & -0.55525 \\
$\mathrm{CO}_{2}$ per $\mathrm{L}$ of milk & 0.0037 & 0.0067 & 0.0049 \\
& & & \\
\end{tabular}

GHG: greenhouse gas emissions; $\mathrm{CH}_{4}$ : methane, $\mathrm{N}_{2} \mathrm{O}$ : nitrous oxide, $\mathrm{CO}$ : carbón dioxide

Results of nutrient excretion are shown in Table 4. When we look at nutrient excretion by animal, our results showed that animals with higher concentrate ratio (high intensive dairies) excreted greater quantities of $\mathrm{N}$ compared to low concentrate ratio (low intensive dairies) i.e., 415 and $392 \mathrm{~g} / \mathrm{d}$, respectively $(P<0.005)$. However, when we compared $\mathrm{N}$ excretion per unit of product, losses were lower in high intensive systems (13.2 $\mathrm{g} \mathrm{N} / \mathrm{L}$ of milk, $P<0.001$ ). Our results were close to those found by Brito \& Broderick (2006), who mentioned that diets containing 50:50 F: C ratio, $25.4 \mathrm{~kg} \mathrm{DMl}$, and $16 \% \mathrm{CP}, \mathrm{N}$ excretion in manure was around $431 \mathrm{~g} \mathrm{~N} / \mathrm{d}$ and $10.5 \mathrm{~g} \mathrm{~N} / \mathrm{L}$ of milk. On the other hand, Groff and Wu (2005) found that when lactating cows were fed diets containing 50:50 F: C ratio, $16.3 \% \mathrm{CP}$ and $24.7 \mathrm{~kg}$ DMI, N excretion was $484 \mathrm{~g} / \mathrm{cow}$ and $13.5 \mathrm{~g} \mathrm{~N} / \mathrm{L}$ of milk. Finally Hristov et al. (2004) mentioned that dairy cows fed $48: 52 \mathrm{~F}$ : C ratio, $15.8 \% \mathrm{CP}$ and $23.5 \mathrm{~kg}$ DMI, shows $\mathrm{N}$ losses in manure of $437 \mathrm{~g} / \mathrm{cow} / \mathrm{d}$. The greatest values per cow of $\mathrm{P}$ excretion were obtained in high intensive systems $(74.9 \mathrm{~g} / \mathrm{d})$ compared with low and medium intensive systems $(P<0.005)$.

However, when $P$ excretions were compared on unit of product basis, high intensive systems showed lower losses $(2.4 \mathrm{~g} / \mathrm{L}$ of milk; $P<0.05)$. Our results were higher in contrast to those made by Weiss and Wyatt (2004) where they show cows consuming $21 \mathrm{~kg} / \mathrm{d}$ producing $30.4 \mathrm{~kg}$ milk $/ \mathrm{d}$ and $\mathrm{P}$ intake of $79 \mathrm{~g} / \mathrm{d}$, excreted $47.7 \mathrm{~g} \mathrm{P} / \mathrm{d}$. In agreement with the present study, Arriaga et al. (2009) reported manure P excretion of about $59.3 \mathrm{~g} / \mathrm{d}$ per cow when $\mathrm{P}$ intake was $84.8 \mathrm{~g} / \mathrm{d}$. For $\mathrm{K}$ excretion in manure, the greatest values per cow were found in high intensive dairies compared with medium and low systems (200, 198 and $192 \mathrm{~g} / \mathrm{d}$, respectively). These results agree with those found by Van Horn et al. (1994) and Nennich et al. (2005), for a lactating cow producing 31.8 and $31.4 \mathrm{~kg}$ of milk/d (K excretion was 204 and $200 \mathrm{~g} / \mathrm{d}$, respectively). Similarly, Kojima et al. (2005) reported high K excretion $(282 \mathrm{~g} / \mathrm{d})$ in cows producing $29.5 \mathrm{~kg}$ of milk/d. Differences were found in $\mathrm{K}$ excretion to the environment per unit of product as well $(P<0.005)$, greatest values of 
excretion were from low intensive dairies, i.e., $7.5 \mathrm{~g} \mathrm{~K} / \mathrm{L}$ of milk compared with high intensive dairies (6.4 $\mathrm{g}$ of $\mathrm{K} / \mathrm{L}$ of milk). Cows in high intensive milk production systems made better use of $\mathrm{K}$.

Table 5 shows the area designated to growing crops and dairy facilities, where low, medium and high

Table 4 Nutrient excretion in manure by total system population, cow and unit of product

\begin{tabular}{|c|c|c|c|c|c|}
\hline & \multicolumn{3}{|c|}{ Level of intensification } & \multirow{2}{*}{ SEM } & \multirow{2}{*}{$P$-value } \\
\hline & Low & Medium & High & & \\
\hline \multicolumn{6}{|c|}{ Nutrient excretion by total population, $g / d$} \\
\hline Nitrogen & 52926 & 115155 & 327475 & 19709 & $* * *$ \\
\hline Phosphorus & 6110 & 14190 & 43151 & 3560 & $* * *$ \\
\hline Potassium & 25887 & 55732 & 157806 & 9415 & *** \\
\hline \multicolumn{6}{|c|}{ Nutrient excretion by cow, g/d } \\
\hline Nitrogen & 392 & 407.5 & 415.4 & 3.63 & ** \\
\hline Phosphorus & 70.6 & 73.5 & 74.9 & 0.68 & ** \\
\hline Potassium & 192 & 197.6 & 200.3 & 1.28 & ** \\
\hline \multicolumn{6}{|c|}{ Nutrient excretion by unit product, g/d } \\
\hline Nitrogen & 15.2 & 13.9 & 13.2 & 0.32 & ** \\
\hline Phosphorus & 2.74 & 2.5 & 2.4 & 0.05 & ** \\
\hline Potassium & 7.5 & 6.7 & 6.4 & 0.03 & ** \\
\hline
\end{tabular}

SEM $=$ Standard error of the mean.

${ }^{*}=P<0.05,{ }^{\star *}=P<0.01,{ }^{* * *}=P<0.001$.

Table 5 Energy, land, and water use for growing crops in three different intensive systems

\begin{tabular}{|c|c|c|c|c|c|}
\hline & \multicolumn{3}{|c|}{ Level of intensification } & \multirow[b]{2}{*}{ SEM } & \multirow[b]{2}{*}{$P$-value } \\
\hline & Low & Medium & High & & \\
\hline Electricity ${ }^{ \pm}, \mathrm{kWh} / \mathrm{mo} \times 10^{3}$ & 64.9 & 81.1 & 288.1 & 13.0 & $* * *$ \\
\hline Gasoline, $\mathrm{L} / \mathrm{mo} \times 10^{3}$ & 0.413 & 0.712 & 2.029 & 0.18 & ** \\
\hline Diesel, $\mathrm{L} / \mathrm{mo} \times 10^{3}$ & 1.36 & 2.26 & 9.88 & 1.70 & ** \\
\hline \multicolumn{6}{|c|}{ Area for growing crops, milk facility and pens } \\
\hline Land, ha & 52 & 114 & 246 & 21.2 & $* * *$ \\
\hline Milk yield, $\mathrm{kg} / \mathrm{ha} \times 10^{3}$ & 19.6 & 25.6 & 30.9 & 4.49 & $* *$ \\
\hline \multicolumn{6}{|l|}{ Main crops, yield (tons/ha) } \\
\hline Corn & 51 & 58 & 61 & 2.6 & $\star * *$ \\
\hline Alfalfa & 16 & 16 & 16 & - & - \\
\hline Triticale & 37 & 40 & 40 & 5 & ns \\
\hline Oats & 10 & 23 & 15 & 2.1 & $* *$ \\
\hline Barley & - & - & 8 & - & - \\
\hline Sorghum & 6 & 8 & - & - & - \\
\hline Wheat & - & - & 2 & - & - \\
\hline Grass & - & 32 & 30 & - & - \\
\hline Water, L/yr $\times 10^{9}$ & 0.74 & 2.17 & 6.51 & 0.29 & $\star * *$ \\
\hline Water, L/L of milk & 611.5 & 857.7 & 865.7 & 51.3 & $* *$ \\
\hline
\end{tabular}

Standard error of the mean. ${ }^{*}=P<0.05,{ }^{* *}=P<0.01,{ }^{* \star *}=P<0.001$, ns $=$ non-significant. 
intensive dairies used 52, 114 and 246 ha, respectively. The main crops grown in the spring-summer cycle was corn, alfalfa, sorghum, triticale and grasses. In the autumn-winter cycle oats are grown. Corn has the highest yield in tons/ha compared to other crops.

Among systems, yield values were highest in high intensive dairies followed by medium, and low intensive systems $(51,58$, and 61 , respectively). Second crop with high yield was triticale with 17,40 , and 40 tons/ha for low, medium, and high intensive systems, respectively. Alfalfa presented the lowest yield with 4 tons/ha, which was similar in all production systems. Highly intensive systems used the greatest amount of water followed by medium and low intensive systems. Most of the water use was for crop irrigation, then for drinking water and finally for cleaning (milk facility and pens that use flushing systems). It is important to mention that farms have permissions to extract water from subsoil at least 9 months a year or through the whole year. Water footprint did not present statistical differences per unit of product. Our results showed that in order to produce one litre of milk, 610,846 , and $870 \mathrm{~L}$ of water were required in low, medium, and high intensive systems, respectively. Our results show lower values compared with those found by Hoekstra and Chapagain (2007), who reported a worldwide water footprint of $990 \mathrm{~L}$ of water/L milk. Furthermore, the same authors mentioned that water required to produce one litre of milk in Mexico was about $2382 \mathrm{~L}$; however, they did not mention if calculations came from an intensive Holstein dairy system or from a dual purpose system (meat and milk production system) or both. This is important because dual purpose systems have very low milk production per cow (4561 kg/cow per year or $15 \mathrm{~kg} / \mathrm{d}$; Espinoza-Ortega et al., 2005). The relatively low water footprint calculated in this study could be because farms visited produced around 40 to $50 \%$ of crops required for animal feed and the rest were purchased or imported.

\section{Conclusions}

Low GHG emissions per unit of product were estimated for highly intensive dairy farms, mainly due to diet composition and efficiency of production. Enteric methane was identified as the major source of GHG emissions, therefore, any mitigation strategy to reduce carbon footprint especially in low intensive milk production systems, should be focused in reducing enteric methane through increasing efficiency of production. Second source of GHG was energy consumption; manure management could be another practice to mitigate carbon footprint through anaerobic digesters in order to produce electric energy and low use of fertilizers on croplands. These practices could make a more sustainable production system. Emission intensity is likely to decrease in the future as cow productivity and management practices are expected to follow trends similar to those in intensive systems.

\section{Acknowledgements}

This research was funded by CONACYT through a doctor of science scholarship (208836) and by UC MEXUSCONACYT Collaborative Grants. Authors also want to thank Tirado G., Mora J.C., Saucedo L.R. and Juárez J., for taking us to the farms and finally to dairy farm owners for allowing us to take the samples and for giving us information.

\section{Authors' Contributions}

JARH doctoral student who conducted the experiment. JMPR \& EK mentors, conception and design, JCGL \& JGV chemical and data analysis.

\section{Conflict of Interest Declaration}

The authors have declared that no competing interests exist.

\section{References}

Aguerre, M.J., Wattiaux, M.A., Powell, J.M., Broderick, G.A. \& Arndt, C., 2011. Effect of forage-to-concentrate ratio in dairy cow diets on emission of methane, carbon dioxide, and ammonia, lactation performance, and manure excretion. J. Dairy Sci. 94, 3081-3093. 234

AOAC, 1990. Official methods of analysis (15th ed.). Association of Official Analytical Chemists, Inc., Arlington, Virginia, USA.

Arriaga, H., Pinto, M., Calsamiglia, S. \& Merino, P., 2009. Nutritional and management strategies on nitrogen and phosphorus use efficiency of lactating dairy cattle on commercial farms: An environmental perspective. J. Dairy Sci. 92, 204-215.

Brito, A.F. \& Broderick, G.A., 2006. Effect of varying dietary ratios of alfalfa silage to corn silage on production and nitrogen utilization in lactating dairy cows. J. Dairy Sci. 89, 3924-3938.

Capper, J.L., Castañeda-Gutíerrez, E., Cady, R.A. \& Bauman, D.E., 2008. The environmental impact of recombinant bovine somatotropin (rbST) use in dairy production. Proc. Natl. Acad. Sci. USA 105, 9668-9673.

Capper, J.L., Cady, R.A. \& Bauman, D.E., 2009. The environmental impact of dairy production: 1944 compared with 2007. J. Anim. Sci. 87, 2160-2167

Dijkstra, J., Neal, H.D., Beever, D.E. \& France, J., 1992. Simulation of nutrient digestion, absortion and outflow in the rumen: Model description. J. Nutr. 122, 2239-2256. 
Espinoza-Ortega, A., Álvarez-Macías, A., del Valle, MC. \& Chauvete, M., 2005. Small-holder (campesino) milk production systems in the highlands of Mexico. Tec. Pecu. Mex. 43, 39-56.

FAO, 2010. Greenhouse Gas Emissions from the Dairy Sector A Life Cycle Assessment. Food and Agriculture Organization of the United Nations, Rome, Italy.

Groff, E.B., Wu, Z., 2005 Milk production and nitrogen excretion of dairy cows fed different amounts of protein and varying proportions of alfalfa and corn silage. J. Dairy Sci. 88, 3619-3632.

Hoekstra, A.Y., 2003. Virtual water trade: Proceedings of the International Expert Meeting on Virtual Water Trade, UNESCO-IHE Value of water research report series, No 12, Delf, The Netherlands.

Hoekstra, A.Y. \& Chapagain, A.K., 2007. Water footprints of nations: Water use by people as a fuction of their consumption pattern. Water Resour. Manag. 21, 35-48.

Hörtenhuber, S., Lindenthal, T., Amon, B., Markut, T., Kirner, L. \& Zollitsch, W., 2010. Greenhouse gas emissions from selected Austrian dairy production systems-model calculations considering the effects of land use change. Renew. Agr. Food Syst. 25, 316-329.

Hristov, A.N., Etter, R.P., Ropp, J.K. \& Grandeen, K.L., 2004. Effect of dietary crude protein level and degradability on ruminal fermentation and nitrogen utilization in lactating dairy cows. J. Anim. Sci. 82, 3219-3229.

Hristov, A.N., Oh, J., Firkins, J.L., Dijkstra, J., Kebreab, E., Waghorn, G., Makkar, H.P.S., Adesogan, A.T., Yang, W., Lee, C., Gerber, P.J., Henderson, B. \& Tricarico, J.M., 2013. Special topics-Mitigation of methane and nitrous oxide emissions from animal operations: I. A review of enteric methane mitigation options. J. Anim. Sci. 91, 50455069 .

IPCC, 2006. Emissions from livestock and manure management. Agriculture, forestry and other land use. Intergovernmental Panel on Climate Change. Geneva, Switzerland.

IPCC, 2013. Climate Change 2013: The physical basis. Contribution of working group I to the fifth assessment report. Intergovernmental Panel on Climate Change, Geneva, Switzerland.

Kebreab, E., Clark, K., Wagner-Riddle, C. \& France, J., 2006. Methane and nitrous oxide emissions from Canadian animal agriculture: A review. Can. J. Anim. Sci., 86, 135-158.

Kebreab, E., Johnson, K.A., Archibeque, S.L., Pape, D. \& Wirth, T., 2008. Model for estimating enteric methane from United States dairy and feedlot cattle. J. Anim. Sci. 86, 2738-2748.

Kojima, H., Kume, S., Nonaka, K., Oshita, T., Kozakai, T. \& Hirooka, H., 2005. Effects of feeding and animal performance on nitrogen, phosphorus and potassium excretion by Holstein cows. Anim. Sci. J. 76, 139-145.

Mott, L.R., 1996. Applied Fluid Mechanics (4th ed.). Prentice Hall Inc., New York, USA.

Nennich, T.D., Harrison, J.H., VanWieringen, L.M., Meyer, D., Heinrichs, A.J., Weiss, W.P., St-Pierre, N.R., Kincaid, R.L., Davidson, D.L. \& Block, E., 2005. Prediction of manure and nutrient excretion from dairy cattle. J. Dairy Sci. 88, 3721-3733.

Phetteplace, H.W., Johnson, D.E. \& Seidl, A.F., 2001. Greenhouse gas emissions from simulated beef and dairy livestock systems in the United States. Nutr. Cycl. Agroecosyst. 60, 99-102.

Place, S.E. \& Mitloehner, F.M., 2010. Contemporary environmental issues: A review of the dairy industry's role in climate change and air quality and the potential of mitigation through improved production efficiency. J. Dairy Sci. 93, 3407-3416.

R Development Core Team, 2012. R: A Language and Environment for Statistical Computing. R Foundation for Statistical Computing. Vienna, Austria.

Rendón-Huerta, J.A., Pinos-Rodríguez, J.M., García-López, J.C., Yáñez-Estrada, L.G. \& Kebreab, E., 2014. Trends in greenhouse gas emissions from dairy cattle in Mexico between 1970 and 2010. Anim. Prod. Sci. 54, $292-298$.

Rotz, C.A., Montes, F. \& Chianese, D.S., 2010. The carbon footprint of dairy production systems through partial life cycle assessment. J. Dairy Sci. 93, 1266-1282.

Servicio Metereologico Nacional. 2017. Información climatólogica. http://smn.cna.gob.mx/es/climatologia/informacionclimatologica

Smith, L.W., 1991. Production systems. In: Handbook of Animal Science. Ed: Putmnam, P.A., Academic Press, USA. pp. 279-291.

Steinfeld, H., Gerber, P., Wassenaar, T., Castel, V., Rosales, M. \& de Haan, C., 2006. Livestock's Long Shadow: Environmental Issues and Options. Food and Agriculture Organization, Rome, Italy.

US EPA. 2016. Greenhouse Gases Equivalencies Calculator - Calculations and References. US Environmental Protection Agency. https://www.epa.gov/energy/greenhouse-gases-equivalencies-calculator-calculations-andreferences

Van Horn, H.H., Wilkie, A.C., Powers, W.J. \& Nordstedt, R.A., 1994. Components of dairy manure management systems. J. Dairy Sci. 77, 2008-2030.

Van Soest, P.J., Robertson, J.B. \& Lewis, B.A., 1991. Methods for dietary fiber, neutral detergent fiber, and nonstarch polysaccharides in relation to animal nutrition. J. Dairy Sci. 74, 3583-3597.

Weiss, W.P. \& Wyatt, D,J., 2004. Macromineral digestion by lactating dairy cows: Estimating phosphorus excretion via manure. J. Dairy Sci. 87, 2158-2166. 